\title{
Sosyolojik Açıdan Covid-19 Salgını: Erzurum'da Kent, Mekân ve Toplumsal Yaşam
}

\author{
İlknur Beyaz Özbey ${ }^{1}$ \\ ORCID: 0000-0001-9809-9085
}

\section{Öz}

Mekân, salt coğrafi bir terim olmanın ötesinde, bireysel ve toplumsal ilişkilerin şekillendiği yer olarak karşımıza çıkmaktadır. Toplumsal yaşam alanının önemli bir dinamiği haline gelen mekânlar, istek, ilgi ve ihtiyaçlar dâhilinde dönüşüme uğramaktadır. Özellikle insanların yoğunlukta yaşadığı kentsel mekânlar, söz konusu değiş̧im ve dönüşümün merkezi haline gelmiştir. Covid-19 salgınıyla birlikte kentsel mekânlar, daha görünür, daha çok risk barındıran ve üzerinde çokça düşünülen bir yer olmuştur. Bu anlamda çalışmanın konusunu, Covid-19 salginı bağlamında kentsel mekan ve mekanın yeniden tahayyülü oluşturmaktadır. Covid-19 salgını kapsamında alınan önlemlerin, gündelik yaşam, ekonomi, eğitim, kültür gibi alanlarda değişim oluştururken; salgının mekân üzerinde de ne gibi değiş̧irip dönüştürücü etkisinin bulunduğu, çalışmanın temel amacını oluşturmaktadır. Bu anlamda bu çalışmada, Erzurum'da kent merkezinde yaşayan 7'si kadın ve 7'si erkek olmak üzere toplamda 14 kişiyle nitel araştırma yöntemi kapsamında derinlemesine mülakatlar gerçekleştirilmiştir. Alan araştırması sonucunda, Covid-19 salgınıyla birlikte, alınan tedbirler kapsamında tek bir yaşam alanının hem eğitim hem çalışma hem de boş vakitlerin değerlendirildiği mekân olarak deneyimlendiğ görülmüş̧ür. Kentsel mekânların avantaj ve dezavantajlarının sorgulandı̆̆ı sonucuna ulaşılmıştır. Insanları kente bağlayan dinamikler kapsamında kentten ayrılamadıkları, fakat kentin dezavantajlarını bertaraf edecek alternatif yaşam alanları oluşturma eğiliminde oldukları anlaşılmıştır.

Anahtar Kelimeler: Covid-19, salgin, mekân, kentsel mekan, Erzurum.

\footnotetext{
${ }^{1}$ Dr. Öğr. Üyesi, Artvin Çoruh Üniversitesi, E-mail: ilknurbeyaz@artvin.edu.tr idealkent @ Kent Araştırmaları Dergisi (Journal of Urban Studies) http://idealkentdergisi.com
} 


\title{
Covid-19 Pandemic from Sociological Aspect: City, Space and Social Life in Erzurum
}

\author{
İlknur Beyaz Özbey² \\ ORCID: 0000-0001-9809-9085
}

\begin{abstract}
Space, beyond being a mere geographical term, emerges as a place where individual and social relations are shaped. The subject of the study is the re-imagination of urban space and space in the context of the Covid-19 outbreak. While the measures taken within the scope of the Covid19 outbreak create change in areas such as daily life, economy, education and culture; the main purpose of the study is what the epidemic has had a transformative effect on the space. In-depth interviews were conducted within the scope of qualitative research method with a total of 14 people, 7 of whom were women and 7 of whom were men, living in the city center of Erzurum. It was observed that with the Covid-19 epidemic, within the scope of the measures taken, a single living space was experienced as a place where both education, work and leisure time were spent. It was concluded that the advantages and disadvantages of urban spaces were questioned. It is understood that they cannot leave the city within the scope of the dynamics that connect people to the city, but they tend to create alternative living spaces that will eliminate the disadvantages of the city.
\end{abstract}

Keywords: Covid-19, pandemic, space, urban space, Erzurum.

\footnotetext{
${ }^{2}$ Assist. Prof., Artvin Çoruh University, E-mail: ilknurbeyaz@artvin.edu.tr idealkent @ Kent Araştırmaları Dergisi (Journal of Urban Studies) 


\section{Giriş}

Küreselleşmenin, birbiriyle iç içe geçmiş dünyanın, farklı risk tecrübelerini de gündeme getirdiği bir gerçektir. Özellikle nüfusun yoğunlaştı̆̆ı kentsel mekânlar, risk ve tehlikelerin merkezi haline gelmiştir. Mekân, kentin ve gündelik yaşamın sorunlarına ek olarak sanayileşmenin getirmiş olduğu sorunları da dâhil etmektedir. Geçmişte karşılaşılan sorunlar tamamen ortadan kalkmaz, varlı̆̆ı devam etmekle birlikte yeniden üretilmektedir (Lefebvre, 2015). Bilim ve teknolojinin gelişmesiyle birlikte kentler, yeniden üretilmekte ve kentsel mekânın yaşanabilirlik açısından sorgulanması gündeme gelmektedir. Kentsel mekân bir kentin ana elementidir. Kentsel mekânlar değişik kullanıcıların paylaştıkları ortak kültürü de ifade etmektedir (İnceoğlu ve Aytuğ, 2009). Kentsel mekânlar kendine ait sorunlarıyla mücadele ederken, bir taraftan da salgınların yıkıcı etkisini bertaraf etmeye çalışmaktadır. Covid-19 salginı, sözü edilen mücadele alanları arasında yer almaktadır.

2019 yılı sonunda, Çin'de ortaya çıkan koronavirüs salgını, Dünya Sağlık Örgütü tarafından pandemi ilan edilmiştir. Küresel Salgın, yani Covid-19, kısa sürede tüm dünyaya yayılmış ve yıkıcı etkiler baş göstermiştir. Tüm dünyayı etkisi altına alan salgın, bireylerin yaşamlarını, alışkanlıklarını, davranışlarını değişime uğratmıştır. Hala etkisini sürdüren salgın, önlenmek adına birçok önlem alınmıştır (Zeybekoğlu-Akbaş, 2020). Covid-19 salgını ortaya çıktığından beri birtakım önlemlerle virüs bertaraf edilmeye çalışılmaktadır. Sosyal izolasyon, sosyal mesafe, kontrollü sosyal yaşam, hayat eve s1ğar, maske, hijyen kuralları, sokağa çıma kısıtlaması, seyahat kısıtlaması bunlardan birkaçını oluşturmaktadır. Ayrıca, insan akışını durdurmak amaçlı, esnek çalışma saatleri, bazı iş yerlerinin kapatılması, eğitimin evde gerçekleştirilmesi, salgın döneminde alınan önlemlerden sayılmaktadır. Alınan önlemlerin bireysel ve toplumsal sonuçları olduğu gibi mekân üzerinde de önemli bir etkiye sahiptir. Toplumsal ilişkilerin şekillendiği mekân, salgın sürecinde de önemli bir değişime uğradığı bir gerçektir. Alınan önlemler, yaşam alanlarını değişime uğratmıştır. Bu anlamda Covid-19 salgını kapsamında alınan önlemlerin, gündelik yaşam, ekonomi, eğitim, kültür gibi alanlarda değişim oluştururken; salgının mekân üzerinde de ne gibi değiştirici etkisinin bulunduğu, çalışmanın temel amacını oluşturmaktadır. Bu amaç çerçevesinde, Covid-19 salgınıyla birlikte, yaşam alanlarının hem eğitim mekânı hem çalışma mekânı hem de boş vakitlerin değerlendirildiği mekân olarak nasıl tasarlandığı, söz konusu değişimlerin gündelik yaşamı, eğitimi, kültürü çalışma hayatını nasıl etkilediğini anlamayı hedeflemektedir. Ayrıca, 
salgınla birlikte kentsel mekânların nasıl risk ve tehlike barındırdığı, bu anlamda kentsel mekânların, avantajı ve dezavantajları kapsamında sorgulandığı ve nihayetinde yeni yaşam mekânlarının nasıl tasarlandığı, çalışmanın temel sorunsalını oluşturmaktadır. Bu sorunsal çerçevesinde, çalışmada, Erzurum'da yaşayanlarla derinlemesine mülakatlar gerçekleştirilerek salgının mekânsal dönüşümü anlaşılmaya çalışılmıştır.

\section{Salgın Hastalıklar ve Covid-19 Salgını}

Tarih boyunca her dönem görülebilen salgın hastalıklar, afet etkisi ile sonuçları bakımından savaşlar kadar yaşamı olumsuz etkilediği gibi toplumsal faaliyetlerin aksamasına, sosyal, ekonomi ve kültürel alanda duraksamalar yaşanmasına neden olarak, insanlığın karşısında en büyük tehditlerden biri olmuştur (Tansü, 2020, s. 4). Özelde devletin ve genelde tüm toplumların salgınlara karşı hazır bulunması gerektiği anlaşılmıştır. Salgınlara karşı nasıl bir tavır sergilenmesi gerektiğinin önemi bir daha vurgulanmıştır (Budak ve Korkmaz, 2020). Bu bağlamda, 2019 yılının sonlarında Çin'in Wuhan kentinde ortaya çıkan Covid-19 salgını, yerel, ulusal, bölgesel ve küresel ölçekte tüm toplumları etkisi altına almıştır.

Covid-19 küresel salgın ilan edildiğinden beri hükümetler tarafından önlemler alınmaya başlandı. Bu önlemler bireylerin ve toplumların alışkın olmadığı bir yaşam tarzını ortaya çıkarmıştır. Alınan önlemlerin, birey ve toplum yaşamı üzerinde önemli oranda etkileri bulunmaktadır. Daha ne kadar süreceği belli olmayan virüs, belirsiz koşulları içermektedir (Afacan ve Avcl, 2020). Müphemliği içerisinde barındıran salgın döneminin, bireysel ve toplumsal olarak kısa ve uzun vadeli sonuçlarıyla karşılaşmaktayız. Hızlı bir şekilde hayatımıza giren Covid-19 salgını, toplum olarak gündelik yaşantımızı sekteye uğratmasına ve sosyo-ekonomik faaliyetlerin durma noktasına gelmesine neden olmuştur.

Küresel bir kriz şeklinde ortaya çkan Covid-19, tüm ezberleri bozmuştur. Gündelik yaşantımızı dahi yapı bozumuna uğratan virüs, hayatta kalmayı başarabilmek adına bir dizi önlemler almaya neden olmaktadır. Sosyal izolasyon, sosyal mesafe, maske, hijyen kuralları, sokağa çıkma kısıtlaması, seyahat kısıtlaması bunlardan birkaçını oluşturmaktadır. Ayrıca, insan akışını durdurmak amaçlı, esnek çalışma saatleri, bazı iş yerlerinin kapatılması, eğitimin evde gerçekleştirilmesi gibi önlemler de salgın döneminde alınan önlemlerden sayılmaktadır. Bu süreçte alınan önlemler gündelik yaşantımızda, sosyo-kültürel ve ekonomik yaşantımızda belirgin değişiklik yaşamamıza 
neden olmaktadır. Başka bir ifadeyle, gündelik yaşantımız ve alışkanlıklarımız ya değişmiş ya da var olanlara yenileri eklenmiştir. Söz konusu değişimlerin başında mekân üzerinde gerçekleşen değişimler yer almaktadır. Bir başka ifadeyle, salgın sürecinde deneyimlenen yaşam pratikleri, paylaşılan mekânların dönüşümüne de neden olmuştur.

\section{Mekân ve Kentsel Mekân}

Mekân, genellikle coğrafi terim olarak karşımıza çıkmaktadır. Arapça kökenli kelime olan mekân aynı zamanda çevre, ortam, yaşanan dünya şeklinde de anlamları bulunmaktadır (Göka, 2001). Harvey'e (2003) göre mekân, ontolojik bir kategori değil, insanı biçimlendiren ve onun tarafından biçimlendirilen toplumsal bir boyuta sahiptir. Mekânsal biçimler, içinde toplumsal süreçlerin oluştuğu cansız nesneler olarak değil, toplumsal süreçleri, bu süreçlerin mekânsal olmasıyla aynı tarzda içeren şeyler olarak görülmektedir. Alver'e (2007, s. 12) göre ise mekân, birey ve toplumların yaşam pratiklerini içermektedir. İnsan, mekân üreten ve kendini mekânla ifade eden niteliğinden dolayı mekânın bir kimlik unsuru olarak ortaya çıkması söz konusudur. Mekân, salt bir yer ifadesi olmanın ötesinde, toplumsal ilişkilerin şekillendiği bir yer olarak ifade edilmektedir. İnsan ilişkilerinin etkilendiği ya da insan ilişkilerinin etkilediği mekân tasavvuru söz konusudur. Modern öncesi dönemde sadece yaşam alanı olarak öngörülen mekân, modern toplumlarda yaşam alanı olmanın yanı sıra, bireysel ya da toplumsal ihtiyaçlar tarafından dönüştürülen, şekillendirilen bir yer olmaktadır. Başka bir ifadeyle insanlar mekânı, kendi ihtiyaçları, ilgileri ve istekleri çerçevesinde değiştirmekte dönüştürmektedir. $\mathrm{Bu}$ durum ise, modernleşmenin bir sonucu olarak karşımıza çıkmaktadır. Kendi ihtiyaçları ve istekleri çerçevesinde şekillenen mekânın değişimi ve dönüşümü sürekli olarak güncelliğini korumaktadır. Bireylerin ve toplumların ihtiyaçları ve istekleri değiştikçe, mekân da o oranda değişime uğramaktadır. Özellikle kentsel mekânlar, sözü edilen değişimin ve dönüşümün en canlı örneklerini sunmaktadır.

Hızlı büyüyen kentlerin cazibesi tartışmasız kabul edilen bir gerçektir. Teknolojik gelişmelere paralel bir şekilde büyüyen kentler, her türlü imkâna rahat bir şekilde ulaşılabilirliğin adresi olarak karşımıza çıkmaktadır. İş ve eğitim başta olmak üzere sosyo-kültürel faaliyetler açısından seçenek çokluğu, kentlerde yaşamı kolaylaştırmakta ve kentte yaşama arzusunu arttırmaktadır. Her türlü imkânın fazla olduğu kentler, söz konusu imkânlar nedeniyle nüfus yoğunluğunun bir numaralı merkezi haline getirmektedir. İnsan akışının çok 
fazla olması kentleri, avantajlarının yanında dezavantajlı durumları da barındırmasına neden olmaktadır. İşsizlik, yoğun trafik, ortak kullanım alanlarının fazlalığı yaşanan dezavantajların başında gelmektedir. Ayrıca söz konusu dezavantajlarının yanı sıra salgınların hızlı bir şekilde yayılmasına neden olmaktadır. Nitekim Covid-19 salgını, insanların yoğun olduğu bölgelerde yani kentlerde daha hızlı yayılırken, risk oranı yüksek olmaktadır. İnsan akışının ve ortak kullanım alanlarının fazla olması, salgın sürecinde kentlerde yaşayanları tehdit eden önemli bir gerekçe olmaktadır. Ayrıca salgın döneminde virüsten korunmak için alınan tedbirlerin merkezi ise yine kentler olmaktadır. Sözü edilen durum ise, kentsel mekânların, yaşam alanlarının ihtiyaca göre şekillenmesine ve dönüşmesine neden olmaktadır.

\section{Yöntem}

Bu çalışmada, nitel araştırma yöntemine başvurulmuştur. Nitel araştırmanın amacı bireylerin kendi toplumsal dünyalarını nasıl oluşturmakta olduğunu anlamak ve içinde yaklaştıkları toplumsal dünyayı nasıl algıladıklarını yorumlamaya çalışmaktır. Nitel araştırma; ne? Nasıl? Niçin? sorularına yanıt aramaktadır. Nitel Araştırma, kuram oluşturmayı temel alan bir anlayışla sosyal olguları bağlı bulundukları çevre içerisinde araştırmayı ve anlamayı ön plana alan bir yaklaşımdır (Kurt, 2013, s. 9). Çalışmada, nitel araştırma yöntemi kapsamında derinlemesine mülakat tekniğine başvurulmuştur. Mülakat ortamında araştırmacının çalışmaya ilişkin sorgulamaları ve bu alanlara ilişkin ek verilerin toplanışı çalışmanın gidişatını belirleyebilecek diğer unsurlardır. Zira elde edilen veriler dile bağlıdır ve dilin dinamik yapısı içinde değişken biçimlerde kendisini sunabilmektedir. Mülakat, sosyal ilişkilerin bilgisini taşır ve konuşma temellidir. Mülakatlar, mülakat veren ve mülakatçı arasında sosyal bir inşa olarak da görülebilir (Kolukırık, 2011, s. 172). Derinlemesine mülakat, çalışmanın sorunsalına dair derinlemesine bilgiler sunmaktadır. Ayrıca elde edilen veriler, çalışmaya dair farklı bir bakış açısı kazanılmasına da katkı sunmaktadır. Elde edilen verilerden belirli alıntılar yapılarak, bireysel ve toplumsal ilişkilerin açıklanması, yorumlanması ve anlamlandırılması sağlanmaktadır.

Bu çalışmanın evrenini, Erzurum'da yaşayanlar oluşturmaktadır. Çünkü Erzurum, Covid-19 salgınının en yoğun yaşandığı kentsel mekanların başında gelmektedir. Erzurum şehri, Erzurum Ovası'nın güneydoğusunda, Palandöken Dağları'nın kuzey eteklerinde kurulmuştur. Şehrin yerleşim alanı güneyde Palandöken Dağları, kuzeyde Karasu Ovası, batıdan Sakalı Kesik Ovası, doğudan ise Deveboynu Geçidi ile çevrilidir. Erzurum şehri 06.03.2008 
tarihinde kabul edilen 5747 sayılı Büyükşehir Belediyesi Sınırları İçerisinde İlçe Kurulması ve Bazı Kanunlarda Değişiklik Yapılması Hakkında Kanun'un 1. maddenin 13. ve 14. fikraları ile 2. maddenin 5. fikrasına göre Aziziye, Yakutiye ve Palandöken olmak üzere üç metropol ilçeye bölünmüştür (Zaman, Sevindi ve Birinci, 2018, s. 582). Çalışmanın örneklemini, Erzurum şehir merkezindekiler oluşturmaktadır. Erzurum'un ilçe ve köylerinde yaşayanlar bu çalışmanın örneklemi dışındadır. Örneklem kapsamında 7'si kadın ve 7'si erkek olmak üzere toplam 14 kişi ile görüşülmüş̧ür. Görüşmeler, görüşülenlerle yüz yüze gerçekleştirilirken; görüşme esnasında, görüşmecilerin de izni alınarak ses kayıt cihazı kullanılmıştır. Ayrıca araştırmacının çalıştığı kurum olan Artvin Çoruh Üniversitesi'nden çalışmayla ilgili olarak Etik Kurul Onayı alınmıştır. Görüşmeler, 28 Eylül-10 Ekim 2020 tarihleri arasında Erzurum il merkezinde gerçekleştirilmiştir. Görüşülen kişilere dair demografik bilgiler, alıntılarla birlikte verilmiştir.

\section{Covid-19 Salgını Sürecinde Mekânların Dönüşümü}

Covid-19 salgınının yoğun olarak yaşandığı Erzurum'da kentsel mekandaki dönüşümü anlamak amacıyla mekan kavramı, eğitim mekanı, çalışma mekanı ve boş zaman değerlendirme mekanı olarak üç farklı bağlamda ele alınmıştır.

\section{Eğitim Alanı Olarak Mekân}

Eğitim, toplumsal etkileşimin ve davranış değişikliği sağlayan bir ilişki türüdür. Toplumsal etkileşim sayesinde toplumun kültürü kuşaktan kuşağa aktarılır. Çocuk, bu şekilde ait olduğu toplumun kültürünü öğrenir. Eğitimden, birey üzerine yapılan ve onun fiziksel, zihinsel ve ahlâksal varlı̆̆ında bir değişikliği ve gelişmeyi gerektiren her türlü eylem anlaşılmaktadır. Yâni bireyin hem kişisel ve hem de toplumsal gelişimi söz konusudur. Bu anlayışla birey, bir bütün olarak ele alınmakta, kendisi ve toplum için en uygun biçimde tüm gelişmesi göz önünde bulundurulmaktadır (Tezcan, 1996, s. 35, 65). Bireysel ve toplumsal gelişme sağlanarak toplumsallaşma gerçekleştirilmektedir. Bu anlamda bireysel ve toplumsal anlamda eğitimin önemi büyüktür. Salgın sürecinde eğitimin devam etmesi önem teşkil etmektedir. Virüsün yayılmasını engellemek ve eğitimin devamının sağlanması anlamında, eğitim evde online şekilde gerçekleştirilmiştir. Söz konusu durum ise, yaşam alanlarının buna göre şekillenmesine neden olmaktadır. Bu anlamda salgın sürecinde eğitim ortamı şu şekilde gerçekleştirilmiştir: 
Şu anda evimiz hem iş ortamı hem eğitim ortamı hem de bir yuva. Bir oda benim, orası ofisim orası oldu. Erkek kardeşime okul ortamı oluşturduk orası kardeşimin sinıfı oldu (K2, 28, Lisans, Bankac1, Bekar).

Virüs ortaya çıtıktan sonra eğitim evde olmaya başladı. Ev ortamını sinıf havasinda oluşturmaya başladık. Mecbur oluşturacaksın, canlı ders var. Öğrenciler var, öğretmen var, o ortamı görüyor, sesleri duyuyor (E3, 39, Lisans, Eczacı, Evli).

Bu süreçte eğitimi evde gerçekleştirmeye başladık. Her ne kadar eğitim çok alamadılarsa. Evin bir köşesi çocuğumun eğitim aldığ köşe oldu (E5, 33, Lise, Esnaf, Evli).

Eğitim çok kötü etkilendi bu dönemde. Çocuklar aldıkları eğitimin yarısını alabildiler. Eğitim evde olunca ev içini de ona göre dönüştürdük. Masasını, odasını. Ses olmayacak şekilde. Sinıfortamı oluşturamadık ama ders dinleyeceği bir alanı oldu (K3, 43, Lise, Kuaför, Evli).

İhtiyaçlar dâhilinde çevre düzenlenerek mekân oluşturma eylemi sergilenmektedir. Bu anlamda insanı, mekânı üreten, değiştiren ve etkide bulunan bir organizma olarak görülmektedir. Başka bir ifadeyle insan, mekânı değiştirip dönüştürmede aktif rol oynayan bir vatlıktır. Söz konusu değişim ve dönüşüm bireysel ve toplumsal ihtiyaçlar dahilinde gerçekleştiği için, pragmatik bir duruş sergilenmektedir (Demir-Kahraman, 2014). Mekân, başlı başına değiştirilen ve dönüştürülen bir yer olarak karşımıza çıkmaktadır. Kendi ihtiyaçlarımız dâhilinde mekânı tasarlayıp, değiştirebilmekteyiz. Salgın sürecinde alınan önlemler, birçok aktivitenin evde gerçekleştirilmesine neden olmaktadır. Dolayısıyla, gerçekleştirilen aktivitelere göre, ev alanı dönüştürülmektedir. Salgın döneminde virüsün yayılmasını engellemek için alınan tedbirlerden birini, evde gerçekleştirilen eğitim olmuştur. Eğitimi canlı ders şeklinde evde sürdürmeye çalışan öğrenciler için, yaşam alanı olan ev, eğitim alanı olarak dönüştürülmüş̧ür. Başka bir ifadeyle, yaşam alanı olan ev aynı zamanda eğitim mekânı olarak bir köşesine konumlanmıştır.

\section{Çalışma Alanı Olarak Mekân (Homeoffice)}

Castells, mekânun analizinde ekonomik, politik ve ideolojik sistemlerin etkisinin bulunduğunu düşünmektedir. Mekân, söz konusu sistemlerin etkisiyle ortay çıkan deneyimler ya da pratikler tarafından şekillenmektedir. Dolayısıyla mekânın salt kendi başına bir anlamı yoktur, toplumsal olarak üretildiği için, toplumsal olarak bir anlamı mevcuttur (Castells, 1991). Mekânı kendi ihtiyaçlarımız çerçevesinde şekillendirip, dönüştürmekteyiz. Salgın döneminde de yaşam alanları ihtiyaçlar dâhilinde şekillendirilmiştir. Özellikle alınan önlemler kapsamında esnek çalışma saatleri ya da homeoffice şeklinde çalışma şartları gelişmiştir. Bu şartlar altında yaşam alanları şu şekilde, değiştirilmiştir: 
Şimdi benim kızım bu süreçte evde çalıştı. O çalışırken bir oda onun oldu. Sessiz ortam olması lazım. Kızım şimdi işe giderken yolda geçireceği vakti kendine ayırıyor. Virüs zamanında evde çalışabilme avantaj oldu. İs yerine de avantaj oldu. Servisten, elektrik faturasından kurtuldu. Çalışanlar için de çok iyi oldu. Bir saat gidiş bir saat dönüş toplamda iki saat boşa yolda geçiyordu. Bu süre şimdi kızıma kaldı. Evde çalışıyor ve maaşın alıyor. İşveren ve işçi açısından baktığında hem masraftan hem de zamandan kazanç sağladılar (E4, 56, Lise, Esnaf, Evli).

Evde çalışıyor olmanın avantajı çok çok iyi oldu. Biz iş yerinde toplu bir şekilde çalışıyoruz. Ortak alanlar çok fazlaydı. Onun dokunduğu yere dokunmak istemiyorsun. Hapşırdı mı hapşırmadı mı bilmiyorum, temiz mi kirli mi bilmiyorum. Ev ortamında çalışmaya başlayınca rahatladım. Kendime ait alan, kimin dokunduğunu biliyorsun. Temiz temiz çalıştım. Hatta daha verimli çalıştım diyebilirim. Evim temiz, masam temiz, bilgisayarm temiz, bunları bilmek beni çok rahatlattı. İs yerinde yaptığım işlemin aynısın evden yapabiliyorum. İş yerini verdiği talepleri daha güzel yerine getirmeye başladım. Müsşeri memnuniyeti daha fazla arttı. Molalarında geçip koltuğa uzanıyorsun, nefes alıyorsun o on dakikada. Kendi evinde kendi bardă̆ınla kahveni yapıp içiyorsun. Dinç geliyorsun ya bu sefer müşteriye daha rahat bilgi veriyorsun, iletişime geçiyorsun müşteriyle. İş yaşamının stresinden uzaksın ayrica. Yani ben avantajını çok fazla yaşadım. Teknoloji nimetlerinden faydalandık açıkçası. Bu işlemleri evden de yapabiliyoruz, iş stresinden uzak. Ayrnca iş yeri de avantajl, servis yok, elektrik tasarrufu yapıyor ayrica. Zamandan avantaj sağlayarak çalışıyorsun bir de, o zaman sana kalıyor. İstediğin şekilde kullan. Bu imkân varmış neden baştan kullanılmadı diye düşünüyorum. Daha güzel ve verimli geçtiğini düşünüyorum(K2, 28, Evli, Bankac1, Bekar).

Pandemi sürecinde ilk iptal edilen çalışmalar gençlik merkezlerinde oldu. Turnuvalarımız vardı Türkiye genelinde onlar iptal edildi. Toplu bütün çalışmalar iptal edildi. Kurs faaliyetlerimiz durdu. Bu tabi ki öğrencilerimiz için kötü oldu. Ama esnek çalışmak çok iyi geldi bana. Uzaktan da çalışabileceğimizi gördük biz. Evden çalışmaktan çok mutluydum. Benim çalışma hayatımda Pandemi süreci sınırları ortadan kaldırdı. Önceden gittiğin ilde katılım sağhlyordun, şimdi ki etkinliklerimize online olarak tüm Türkiye'den katılım să̆lanıyor (K5, 32, Lisans, Gençlik Lideri, Bekar).

Evden çalışmanın kolay yönleri var. Evden çıkmıyorsun, çocukları başka bir yere bırakmıyorsun. Şöyle bir olumsuz yönü oldu, çocuklarn hepsi derse girsin diye ders saatlerimizi yaydik. Akşam sekizde de canlı dersim var, hafta sonları canlı dersim var. Ilk zamanlar okula gitmediğimiz için bir rahatlık oldu, ama özel hayat kalmadı. Özel hayatım da kamusal hayat oldu. Kamusal hayat beşte bitiyordu ama gece, hafta sonlarn da hep ögrrencilerle ders yapryoruz. Gece saat on iki de yazan mi dersin, soru soran mi oldu. Gece gündüzüm hep kamusal hayat oldu (K6, 31, Lisans, Öğretmen, Evli).

Homeofiste çalışan bir arkadaşım var. Bıktım diyor artık. Sürekli evdesin sürekli evdesin. Sosyal hayat sıfir diye sürekli şikayet edenler var. En azından işe giderken sosyalleşiyorduk. Başka bir insan yüzü görüyorduk. Ben öyle düşünmüyorum. Öyle 
firsatım varken neden işe geleyim ki. Kalan zamanı istediğim gibi değerlendiririm. Servisle o kadar yol gitmiyorlar, yemeklerini en să̆lkkl bir şekilde evlerinde yiyorlar (E7, 35, Lisans, Avukat, Evli).

Homeofis gibi imkanı olup da gelip burada yer işgal etmeyi hiçbirimiz istemeyiz herhalde. Bize de esnek çalışma saati vardı. O bile ne kadar iyi geldi bize. Üç kişinin bakacağı hastaya 10 kişi bakıyorduk önceden. Esnek mesai saati çok iyi oldu. İnsanlar çok fazla zaman harcamadan yorulmadan çalıştı. Keşke mesai saati kavramı hesaplanmasa da ne kadar iyi verim alını ona bakılsa. Keşke böyle devam etse bizde de. Haftada iki gün geleyim. Diğer arkadaşım da öyle. Böylece sıkılmadan daha verimli çalışmış oluruz. Virüs zamannda hepimiz geldik ve daha fazla da birbirimize bulaştırdık (K7, 29, Lise, Sağlık Çalışanı, Evli).

Bazı mesleklerde iş yeri ihtiyacı var. Ama bazı mesleklerde böyle bir ihtiyaca gerek olmadığın gördük. Boş yere yer işgali. Aynı işi evinde yapabilecekken, kafası daha rahat olacakken, iş yerinin stresine ne gerek varmış. Hem kendine vakit ayıracakken, o kadar süre boşa gitsin. Burada işimiz bitti mi saatlerce oturmak zorundayız. Evde olsan bu süreci başka şeylerle meşgul olarak geçirebilirsin. Burada o saatle boşa gidiyor. Neden işgal edeyim $k i$, israf bence. Daha faydah olduğunu düşünüyorum. Psikolojik olarak da çalş̧anlara çok şey kattığın düşünüyorum. Çünkü biz burada bir yerden sonra desteğe ihtiyaç duyuyoruz psikolojik olarak. Sürekli gidiyorsun, sürekli geliyorsun, iş yerinde ayr bir sikıntı, stres. Sonra ne oluyor uzun bir süre tatile ihtiyaç $d u-$ yuyoruz. Ama uzaktan yapılacak bir iş varsa neden işe gelip gideyim ki, evimden hallederim (E1, 30, Lisans, Zabıt Katibi, Bekar).

Salgın döneminde dönüşüme uğrayan bir diğer alan ise, çalışma hayatı olmuştur. Gerek esnek çalışma saati gerekse homeoffice şeklinde çalışma hayatı sürdürülmeye başlandı. Bu anlamda salgın dönemi, bazı işlerin, belirli iş yerine gerek duyulmadan, evden gerçekleştirilebileceğini göstermiştir. Salgın sürecin, dezavantajlarının yanında en olumlu yanı, esnek çalışma saatleri ve belirli mekâna gerek duyulmadan çalışma hayatının sürdürülmesi olmuştur. Dolayısıyla bu durum, yaşam alanı olan evin bir kısmının, çalışma mekânına dönüştürülmesine neden olmuştur. Başka bir ifadeyle, ev ortamı aynı zamanda çalışma mekanı olarak yaşam alanına eklemlenmiştir.

Sözü edilen çalışma şeklinin birçok avantajı bulunmaktadır. İşveren ve çalışan açısından zaman ve ekonomik olarak tasarruf sağlamış olmasıdır. İşveren açısından, çalışma mekânın giderleri ve çalışanların giderleri olmadan aynı işin yürütülmesi büyük bir avantaj olmuştur. Çalışan açısından ise, iş yerine gidiş geliş zamanı ve masrafından tasarruf sağlanmıştır. Yolda geçireceği süreyi kendine ayıran çalışanın, dinlenme süresi artmıştır. Dolayısıyla 
dinlenme süresi artan çalışanın, iş veriminde yükselme olmuştur. Ayrıca, çalışma hayatının kendine ait stresinden uzak evde daha rahat bir şekilde çalışma hayatını deneyimleyen bireylerde yine iş verimliliği artmıştır. Aynı zamanda çalışan annelerin çocuklarını herhangi bir kuruma ya da yardımcı elemanlara bırakmadan kendilerinin ilgileniyor oluşları da büyük bir avantaj olarak karşımıza çıkmaktadır. Söz konusu avantajların yanında dezavantajları da bulunmaktadır. Özel hayatın içerisine kamusal hayatın dâhil edilmesi, dezavantaj olarak karşımıza çıkmaktadır.

Kamusal alan, kent meydanları, agoralar, mahkemeler ortaklığı ve birlikte eylemde bulunma pratiğini ifade etmektedir. Siyasal olarak karar almakta özgür yurttaş ve bireylerin yer aldığı siyasal bir mekândır. Söz konusu siyasal mekânda hem alınan kararlar aktif rol oynayan hem de alınan kararlara uymayı gerektirmektedir. Duygu alanı özel alanı ifade etmektedir. Toplum ç1karının mevcut olmadığı, özel çıkarların hakim olduğu alandır özel alan (Odabaş, 2018). Kamusal alan, toplum çıkarlarının merkezi konumda olduğu bir alanı ifade etmektedir. Ev alanı, özel hayatın sürdürüldügü mekânlardır. Salgın öncesinde özel hayatın mekânı olan ev, salgın döneminde çalışma hayatının sürdürüldüğü mekân haline de gelmiştir. Dolayısıyla özel alan, aynı zamanda kamusal alan haline gelmiştir. Bu durum özellikle evli ve çocuk sahibi olan bireyleri olumsuz yönde etkilemiştir. Tek bir mekân içerisinde, anne-baba, eş ve aynı zamanda çalışan birey rollerini sürdürmeleri gerekmektedir. Bu anlamda özel alanın kamusal alana dönüşmesi, bireyleri zorlayan bir nokta olarak karşımıza çıkmaktadır.

\section{Boş Zaman Değerlendirme Olarak Mekân}

Dünyada salgın süreci; insanın birçok alışkanlığından vazgeçmesi, bazı alışkanlıklarında önemli değişikliklere gitmesi ayrıca bazı yeni alışkanlıklar edinmesi anlamina geliyor (Gönül, 2020, s. 49). Söz konusu değişimler kapsamında alışkanlıklarımız gelmektedir. Çalışma ve eğitim hayatımızın yanı sıra boş vakitleri değerlendirdiğimiz aktivitelerde de bir değişiklik olmuştur. Özellikle vakit geçirilen mekânların değişikliği ve yaşam alanlarının buna göre şekillenmesi söz konusudur. Başka bir ifadeyle salgın sürecinde boş vakitlerimizi değerlendirdiğimiz ilgi alanları (mekânları) değişmiştir. Bu anlamda boş zamanların değerlendirilmesi kapsamında yer alan mekânlar şu şekilde değişmiştir:

Pandemi sürecinde açık hava mekânları daha çok tercih edildi. Açık havada sıkıntı olmaz diye düşünülüyor. Kapalı alanlarda da fazla kişi var mı, buna dikkat edildi. Kapalı mekânlarda kalabalıssa, kalabalık olmayan kısımlarmı tercih ediyoruz. Bu süreçte açıkçası çok fazla gitmemeyi tercih ediyorduk. Hatta bazen görüyorum bazı açık hava 
mekânlarını o kadar kalabalık ki açık havası kalmamış (E1, 30, Lisans, Zabıt Katibi, Bekar).

Bizim evin balkonu çok büyük olduğu için pandeminin ilk dönemlerinde çocuklar da biz de hiç sıkılmadık. Vaktimizin büyük çoğunluğunu orada geçiriyorduk. Çocuklar orada oynuyordu. Ev anlamında biz bu konuda şanslıydık. Kayınvalidemin evinde balkon yok, güneş de görmediği için onlar daha çok sıkıldılar. Biz hiç sıkılmazken, onlar bir an evvel bitsin, dışarı çıkalım diye düşünüyorlardı. Evin koşulları iyi değilse, sıkılmalara o oranda arttı doğal olarak (K1, 31, Lisans, Öğretmen, Evli).

Benim annem babam köyde yaşıyor. Bu dönemde çok rahat oldu onlara. Hiç sıkılmadan yaşadılar. Ben çalışıyordum. Eşim ve çocuklarım çok sıkıldılar. Ara ara firsat buldukça köye kaçıyorduk biz de (E3, 39, Lisans, Eczac1, Evli).

Balkonu olanlar bile çok rahat geçirdi bu süreci. Ailen dışında kimseyle görüşemiyorsun, toplu tüm mekânlar yasak. Ne kalıyor geriye, yeşillikli geniş alanlar. Ya bahçeli güzel bir evin olacak ya da köy gibi sakin bir hayatın olacak. Ya da güzel geniş bir balkonun olacak. Ben bu üçünden de mahrumdum. Bu süreçte insanlarm evle ilgili planları bile değişti. Ben önceden ev almayı düşünürken bahçeli bir eve bakmıyordum, büyük bir site olsun ona bakıyordum. Şimdi balkonu geniş olsun, bahçesi olsun diye bakıyorsun (K6, 31, Lisans, Öğretmen, Evli).

Mekân, bireyin ve toplumun yeridir. Mekân, insan ilişkilerinin şekillendiği bir boşundur. Bu anlamda mekânı anlamada öncelikli olarak bireyin varoluşsal değeri gelmektedir. Daha sonra çevre üzerindeki örgütlenme düzeyi yer almaktadır. Başka bir ifadeyle mekan, insan ilişkilerinin şekillendiği, donatıldığı, eylemsel pratiklere döküldüğü bir yer olarak karşımıza çıkmaktadır (Gür, 1996, s. 43-45). Salgın sürecinde vakit geçirilen mekânların önemi artmıştır. Başka bir ifadeyle, vakit geçirilen mekânlar üzerinde düşünsel faaliyetler yoğunlaşmıştır. Salgın döneminde, virüsün yayılmasını engellemek için alınan önlemlerden birisi, getirilen kısıtlamalar ve insanların birçoğunun evde kalmasıdır. Bu süreçte vakit geçirilen mekânların, özellikle yaşam alanlarının mahiyeti sorgulanmıştır. Başka bir ifadeyle boş vakitlerin değerlendirildiği mekânlar kısıtlanmış, vakit geçirilen mekânların başında ev ortamı yerini almıştır. Dolayısıyla ev, salgın sürecinde boş vakitlerin geçirildiği mekân olarak karşımıza çıkmaktadır. Aynı zamanda, bahçeli, balkonlu, balkonu geniş evler ya da kırsal mekânlarda bulunan evlerin, salgın sürecinde avantajlı bir konumda olduğu görülmüştür. Sözü edilen mekânların dişındaki mekânlar, salgın sürecinde bireyleri olumsuz yönde etkilemiştir. Ayrıca sosyal aktiviteler için, açık hava mekânları daha çok tercih edilir olmaktadır. Kapalı mekânlar virüsün yayılma tehlikesinden dolayı tercihler arasında yer almamaya başlamıştır. 


\section{Salgın Şartlarında Kentte Yaşamak ve Risk}

Modernizm kentler üzerinde kurulmuş ve hayatiyetini bunun üzerinden devam ettirmektedir. Modern kent yaşamı kalabalık nüfusu üretim ve pazarlama ağları ile yoğun nüfusun yoğun ilişkileri arasında karmakarışık bir ağdır. İnsan ilişkilerinin iç içe geçtiği ve milyonlarca insanın sınırlı bir coğrafi mekânda yaşamaya zorlanması, kentlerin modern dünyada cazibe merkezi haline getirilmesiyle irade dışı bir şekilde insan kitlelerini kendine çekmektedir. Salgının kentsel yaşam ve kentsel demografi üzerinde doğrudan ve dolaylı etkileri olacağı söylenebilir (Taştan, 2020, s. 39). İnsan yoğunluğunun ve akışının fazla olduğu kentlerde salgın daha farklı boyutta ilerlediği görülmektedir. Bu anlamda kentte yaşayan insanların salgın sürecindeki deneyimleri şu şekildedir:

Evde kapalı kalmak çok korkunçtu. Hep alı̧kmız dışarı çıkmaya, işe gitmeye. Çok da dikkat etmediler. Dikkat etmedikleri içi çok yayıldı. Tamam senin bağışıklık sistemin güçlü, ama benim güçlü değil. Ben kendimi iyi hissediyorum ben de bir şey yok düşüncesi çok fazla (K4, 44, Lise, Kuaför, Evli).

Apartmanda yaşamak bu durumda bizim için dezavantaj oldu. Herkesin kullandı̆̆ı asansörü kullanıyorsun. Herkesin kullandığı kapıdan girip çıkıorsun. Büyük bir risk. Bahçeli evi olanlar ya da sadece kendi kullandığı mekanlarda yaşayanlar daha avantajl bence (E1, 30, Lisans, Zabit Katibi, Bekar).

Bu süreçte daha kuymetli oldu köylerimiz. Kimseyle karşlaşmıyorsun, ortak kullanım alanların kısıtll, her şey sana ait. Burada öyle bir şey yok ki. Burada çocuklar dışarı çıkamadı. Komşuluk olayı bitti. Dört duvar arasında kendi kaderinle yalnızsın. Apartman hayatında, kimin kiminle görüştüğ̈̈nü ne tür virüs taşıdlğın bilmiyorsun. Yabancısin. Köydeki insanlar öyle mi? Herkes birbirini tanıyor, kiminle görüştüklerini biliyorsun. Ne tür tehlike var hepsini biliyorsun (E5, 33, Lise, Esnaf, Evli).

Korunakl bir yer ev, ama her şeyi karşılamıyor İnsanın bir nefes alma dönemi oluyor. Bir enerjimi atman lazım diyorsun. Psikolojik olarak çöküyorsun, ev yetmiyor, camdan bakıyorsun olmuyor. Dışarı çımıyorsun virüs var. Evler yetmedi bu anlamda. Markete gittiğinde öndeki paketi değil de arkadaki paketi alayım diyordun (K2, 28, Lisans, Bankac1, Bekar).

Kentte her yer ve her şey çok dolu. Her imkana çok rahat ulaşıyorsun ve seninle beraber herkes ulaşıyor ve büyük bir risk. Bu dönemde çoğu insan köyleri varsa köylerine gittiler. İmrenmedim desem yalan olur. Özellikle çocuklar için (K6, 31, Lisans, Öğretmen, Evli).

Apartman dairelerinde yaşayanlar balkona çıkarken bile tedirgin oluyordu. Ama köyde yaşayanlar öyle değil. Bahçe senin. O musluğu bir tek sen kullanıyorsun. $O$ merdivenleri bir tek sen kullanıyorsun. E bahçede otursan kafan dağllmış olur, rahatlarsın. Sokağa çıma yasă̆ımın olduğu zaman sabah kalktık. Dışarıda hiç kimse yok. 
Ses bile yok. Kayıp şehir gibi olmuştuk. Sadece kedi köpek hayvan sesleri vardı. Şehir hayvanlara kalmıştı. Bazı şehirlerde dă̆da yaşayan hayvanlar şehre inmişti. Tertemiz bir hava vardı araba gazları yoktu. Düşünsene sokă̆a çıkma yasağının olduğu zamanlar o temiz havayı soluduk, köyde yaşayanlar her gün. Şehirde yaşamak zor. Her yer ortak kullanım alanı. Sen ben dışarı çıkmadık ama sağlık çalışanları çıkmak zorundaydl, polisler çıkmak zorundaydl. Şu an kentte yaşamak çok dezavantajlı hale geldi. Sokağa çıkmaya korkar olduk. Otobüsleri kullanmaya korkar olduk. Aman bize virüs bulaşır mı diye. Çünkü sosyal hayat daha tehlikeli (E7, 35, Lisans, Avukat, Evli).

Kent şu anda daha dezavantajl konumda. Apartman dairesinde yaşıyorsun. Asansöre biniyorsun adam maskesini takmamıs. Uyarsan bir dert uyarmasan başka bir dert. Sana bulaşma riski var. Benim annemin bahçeli evi var. Kendine ait. Kimsenin riski altında değil. Ama biz öyle değiliz, herkesin dokunduğu alana dokunmak zorundasin (E2, 35, Lisans, Eczacl, Evli).

Kent ne kadar büyük olursa, o kadar çok insan demek, o kadar çok akış demek, o kadar çok virüsün yayılması demek. Bizim hastane personelin ayr bir lavabosu yok. Biz hastalarla aynı lavaboyu kullanıyoruz. Ortak alanlar çok fazla. Çok tehlikeli. Insan akışı çok fazla çok çabuk yayılıyor. Virüslü hastaların kullandiğı ayrıca bir asansör yok. Insanlar bilinçli olsa, maskesini taksa, temizliğine dikkat etse belki o kadar sıkıntı olmayacak. E sen hapşırıyorsun, o elle asansöre dokunuyorsun, sonra ardından sen bas, tabi ki sana bulaşacak virüs. Sadece Erzurum olsa hadi neyse, kırsal kesimden gelen binlerce hasta var, hangi birisini kontrol edeceksin. Hastanede dikkat edebildiğ imiz kadar ediyoruz ama nereye kadar bir sürü hasta girip çıkıyor. Ama köyde yaşayanlar bunu daha kolay bir şekilde atlattılar. Herkes herkesi tanıyor biliyor. Burada markete gitmek zorundasın, manava gitmek zorundasın, çalışmak zorundasın (K7, 29, Lise, Sağlık Çalışanı, Evli).

Covid-19 salgınının küresel çapta meydana getirdiği şok etkisi ve sebep olduğu zihinsel travma, kentlerin geleceğinin ve kent planlamanın işlevinin de yeniden sorgulanmasına yol açmıştır. Covid-19 salgınının yayılma hızı, aşırı büyüyen azman kentler için küreselleşmenin hediye ettiği yeni bir olumsuz dişsallık olarak tebarüz etmiştir. Her ne kadar, küresel tedarik zincirleri ve insan hareketliliği sebebiyle kısa sürede dünyanın her kıtasına ve hemen her ülkeye yayılmış olsa da, salgının yayılma hızının, büyük ve kalabalık kentlerde daha yüksek olduğu bir vakıadır (Paköz, 2020, s. 23). Salgın sürecinde kentte yaşamak büyük bir dezavantaj haline gelmiştir. Kentler, yapıları gereği insan yoğunluğu çok fazla olan mekânlardır. Dolayısıyla kentsel mekânlarda, insan akışı ve ortak kullanım alanları da yoğunlukta bulunmaktadır. Söz konusu yoğunluk, salgın döneminde büyük bir dezavantaj oluşturmaktadır. Ortak kullanım alanlarının ve insan yoğunluğunun fazla olması virüsün o kadar hızlı yayılmasına neden olmaktadır. Aynı asansörü kullanmak, 
aynı tuşlara basmak, aynı marketten alış veriş yapmak, aynı otobüsü kullanmak gibi dezavantajlar, kentte yaşayan insanları olumsuz yönde etkilemiştir. Özellikle salgın döneminde daha izole bir yaşam, ortak kullanımların daha az nitelikte olduğu alanlar daha çok tercih edilmeye başlanmıştır. Bu anlamda salgin sürecinde kentte yaşayan insanların, kentteki yaşam pratiklerini sorgulamalarına, kentin avantaj ve dezavantajları üzerinde düşünmeye sevk etmiştir.

\section{Kentte Yaşamayı Yeniden Düşünmek ve Yeni Mekân Tahayyülü}

Salgın genel olarak insandan insana bulaşarak yayılmaktadır. Bu noktada köy veya şehir ayrımı yapmamaktadır. Dolayısıyla nüfusun daha yoğun olduğu özellikle metropol ve büyük şehirlerde insanlar arası temasın daha fazla olduğu yerleşim yerlerinde bulaşma riski daha fazla görünmektedir. Şehir yönetimlerinin böylesi salgın durumlarda temel gereksinimlerin asgari düzeyde de olsa kesintiye uğramadan sağlanması hususunda hazırlıklı olması gerektiği açıkça görülmektedir (Taştan, 2020, s. 36). Bu anlamda kentte yaşayan insanların salgın döneminde, kentteki yaşam pratikleri üzerindeki düşünceleri şu şekilde değişmiştir:

Apartmanda yaşayanlar hapis hayatı yaşadı. Bahçeli evleri olanlar bahçesinde vaktini geçirdi. Köyde yaşayan adamın maske takmaya ihtiyacı yok zaten. Köyde fala insan yok ki, teması olsun. Köyde yaşayan insanlar rahat. Şu an imkanım olsa, çocukların okulu olmasa gider köyde yaşarım. Çocuklarm eğitimi bizi bağlıyor, o yüzden şehirde yaşamak zorundayım (E4, 56, Lise, Esnaf, Evli).

Ev bana yetersiz geldi. Ben kırsal kesimde yaşama isteğim iyice arttı (E6, 42, Yüksek Lisans, Öğretmen, Evli).

Önceden köyden kentlere göç yaşanırdl, bu salg̨n bize kentten köye göçü yaşandtğın gösterdi. Kentin albenisi çok fazlaydı, ama şu an kentler dezavantajlı konuma girdi. Dıı̧arı çıkayım, ayağım toprağa bassın ama kimse basmamış olsun, sana ait, bir alan istiyorsun. Şimdi herkes dubleks bahçeli evim olsun istiyor (K2, 28, Lisans, Bankacı, Bekar).

Keşke bahçeli evimiz olsaydı. Keşke köyde yaşasaydık. Apartman hiçbir zaman bana cazip gelmemişti, şimdi iyice sorunlu bir yer oldu. Evden çıktıktan sonra ayağın toprağa basmall, bunun önemini anladık. İki yılda nasıl binalaşma oldu anlamadım. Yeşillik kalmadı. Şimdi buna daha çok dikkat ediyoruz (K3, 43, Lise, Kuaför, Evli).

Bizde pandemiden dolayı ş̧̈yle bir fikir oluştu, bir arsa alıp kendimize hobi bahçesi oluşturmak. Şu an bunun için buna çalışmaya başladık. Bütün birikimimiz bu yönde. Gerekirse işe buradan gidip gelebiliriz. Şahsıma ait özel alanlar oluşturmak istiyorum. Çoğu insanda köye kesin dönüş yapmaya başlıyor. Ne duyuyorsam planlarmı değiştirdi insanlar. Doğaya dönüş başladı. Önceden yürüyüş planlardık öğrencilere, öğrenciler şikayet ederdi. Şimdi yürüyüş olsun yapalım diyor, öğrenciler. Etkinliklerimizi 
bile değişti. Önceden gençler merkezdeki etkinliklere yönelirdi (K5, 32, Lisans, Gençlik Lideri, Bekar).

Daha sık kontrollerin olduğu yaşam alanlarma ihtiyacımı var. Kentte yaşamak zorundayız, hepimizi bağlayan şeyler, ama daha sık kontroller olmal. Sadece bu virüs için demiyorum başka salgınlar, başka sorunlar da olabilir. Biraz daha denetim ve kontrolün artması lazım. Herkesin farkında olması lazım. Bilinçli olması lazım (K7, 29, Lise, Sağlık Çalışanı, Evli).

Müstakil evler, kırsal yaşamin daha kıymete bindiğini düşünüyorum. Kentte yaşama şu haliyle çok tehlikeli ve sıkıcı olmaya başladı. Geçenlerde teknede yaşamayı tercih edenleri gördüm. Herkesten ve ortak kullanmm alanlarmndan uzak (E2, 35, Lisans, Eczacl, Evli).

Apartman dairesinde yaşıyorsun. Ortak kullanımlar çok fazla. Normale dönmezse sosyal hayat bitiyor. Insanlar daha çok birbirini yemeye başladı. Sosyal hayatta insanlar stresini atıyor. Açık alanlar olsa belki sıkıntı olmaz. Ablamın villası var, kendilerine ait eode bahçede daha rahattı, riskten uzaktı. Diğer ablamın apartman dairesinde çocuklar birbirini yediler. Toplu değil de açık alanlara ihtiyaç var. Bireysel alanlar diyemem çünkü insan arkadaşsız, sosyal çeoresiz yapamaz. Daha korunakl yerler olması gerekiyor (K6, 31, Lisans, Öğretmen, Evli).

Annem babam buranın ilçesinde yaşıyorlar. Virüsten önce ilçeyi bir tık geride bırakmıştı. Ama şimdi ilçeye gitmek için can atıyoruz. Orada herkes birbirini tanıyor, bahçeli evimiz var. Korunaklyyı en azından. Virüsten uzak, rahat bir şekilde vakit geçiriyoruz aslında. Köyler şu an çok çok kaliteli olmaya başlandı. Köylere, ilçelere akın etmeye başladılar. Bu dönemde sık sık gittik. Keşke orada yaşasaydık dedik yeni. Şu an şehirde yaşamak dezavantajlı oldu bizim için (K4, 44, Lise, Kuaför, Evli).

Eğer mekân bir ürünse, bilgi bu üretimi yeniden-üretecek, onu sergileyecektir. İlgi ve nesne, mekân içindeki şeylerin yerini bizzat mekânın üretimine kaydırır. Bu, mekânı altüst ederek mekâna dâhil olabilen toplumsal üretim ilişkileri içindeki çelişkilerin etkisidir. Her üretim tarzı kendine uygun mekâna sahip olduğundan, bu geçiş sırasında yeni bir mekân üretilir (Lefebvre, 2015, s. 66, 74-75, 111) Mekân, toplumsal bir yapı olmasından dolayı, sürekli sorgulanmakta, değişmekte ve dönüştürülmektedir. Söz konusu dönüşüm, insanların ilgileri ve ihtiyaçları kapsamında gerçekleştirilmektedir. Nitekim salgın döneminde de yaşam alanları, kentsel mekânlar artıları ve eksileriyle sorgulanmış, yerine yenileri tahayyül edilmiştir.

Salgın döneminde kentsel mekânlarda yaşamanın dezavantajlı bir durum olduğu anlaşılmıştır. İnsan yoğunluğunun, insan akışının ve ortak kullanım alanlarının fazla olması büyük bir risk alanı oluşturmaktadır. Yine salgın dö- 
neminde apartman dairelerinde yaşamak, insanların hareket alanının kısıtlanmasına neden olmaktadır. Buna karşılık, bahçeli evleri olanlar ya da kırsal mekânlarda yaşayan insanlar daha avantajlı konumdadır. Yaşam alanları kendilerine ait ve ortak kullanım alanları sınırlı olduğundan dolayı virüsün yayılma oranı düşüktür. Bu anlamda salgın dönemi, kentsel mekânlarda yaşayan insanları, yaşama alanları ile ilgili bir düşünüşe sevk etmiştir. Kentsel mekânların cazibeliğini yitirdiğini söylemek zor olsa da, alternatif yaşam alanlarının oluşturulma eğiliminin fazla olduğu görülmektedir. İş, meslek, eğitim, sosyal aktivitelerin çok çeşitli ve imkân sahasın çok geniş olması, insanları kente bağlamaktadır. Bir yandan da Covid-19 salgınıla birlikte kentsel mekânlarda yaşamanın zorluğu anlaşılmıştır. Bu anlamda insanlar, kentsel mekânlarda alternatif yaşam alanları oluşturmaya başlamıştır. Hobi bahçesi, bahçeli evler ya da kırsal mekânlarda yaşamayı tercih edenler olmuştur. Fakat yaşam alanını değiştirecek herhangi bir imkâna sahip olmayanlar da ise, kentsel mekânların bağlayı yönlerinin fazla olduğu ve salgınların hayatımızın bir gerçeği olduğu düşüncesi bulunmaktadır. Bu anlamda kentsel mekânların, insanların salgın dönemlerinde, tehlike oluşturmadan rahat hareket sahalarının bulunmasına yönelik önlemlerin alınması gerektiğini düşünmektedir. Covid-19 salgını, söz konusu düşünce ve eylemlerin farkındalığını arttırdığı yönünde önemli bir sonucu ortaya çıarmıştır.

\section{Sonuç}

İnsan ilişkilerinin karmaşıklaştığı, iç içe geçtiği ve buna paralel olarak insan akışının hız kazandığı bir dönemde yaşamaktayız. Teknolojinin gelişmesiyle birlikte hızla artan bir nüfus ve artan nüfusla birlikte ortaya çıkan risk ve tehlikeler bulunmaktadır. Özellikle nüfusun yoğun olduğu mekânlar yani kentsel mekânlar, tehlike ve risklerin merkezi haline gelmiştir. Başka bir ifadeyle küreselleşmenin risklerine en fazla ortak olan kentsel mekânlardır. Özellikle salgın hastalıklar söz konusu olduğunda, yayılma hızı ve etkisi bakımından kentsel mekânlar büyük bir risk barındırmaktadır. Kentsel mekânlar, kente ait sorunlarla mücadele ederken başka bir taraftan salgınların yıkıcı etkisini ortadan kaldırmaya çalışmaktadır. Bu anlamda Covid-19 salgını, söz konusu mücadele alanlarından birini oluşturmaktadır. Covid-19 salgınını bertaraf etmek için birtakım önlemler alınmaktadır. Alınan önlemler, birey ve toplum yaşamı üzerinde değiştirici etkileri bulunurken; toplumsal yaşamın şekillendiği mekânı da değiştirip dönüştürmektedir. Mekân değişirken, aynı zamanda 
bireysel ve toplumsal yaşam alanları sorgulanmakta, Covid-19 salgını ile birlikte yeni yaşam alanlarına ihtiyaç duyulduğunun farkındalığı artmaktadır. Bu anlamda Covid-19 salgınının mekân üzerinde etkisi ve sonuçları şu şekildedir:

1. Genel anlamda kendi ihtiyaçlarımız dâhilinde mekânı tasarlayıp, değiştirebilmekteyiz. Bu anlamda salgın sürecinde yaşanan dönüşüm, insanların yaşam alanları üzerinde etkisi bulunmaktadır. Alınan tedbirler kapsamında eğitim, okul ortamından uzak, evde gerçekleştirilmiştir. Bu durum, evin bir köşesinin eğitim mekânı olarak tasarlanmasına veya dönüşmesine neden olmuştur.

2. Aynı zamanda çalışma hayatının esnek ya da işyerlerinden uzakta bir şekilde gerçekleştirilmesi, insanların boş vakitlerinin çoğunu evde geçirmeye başlamasına neden olmuştur. Dolayısıyla bu durumun evdeki yaşam alanının bir köşesinin çalışma mekânı olarak kalmasına neden olmuştur. Bu durumun birkaç avantajı ve dezavantajı bulunmaktadır.

3. İşveren ve çalışan açısından zaman ve ekonomik olarak tasarruf sağlamış olmasıdır. İşveren açısından, çalışma mekânın giderleri ve çalışanların giderleri olmadan aynı işin yürütülmesi büyük bir avantaj olmuştur. Çalışan açısından ise, iş yerine gidiş geliş zamanı ve masrafından tasarruf sağlanmıştır. Yolda geçireceği süreyi kendine ayıran çalışanın, dinlenme süresi artmıştır. Dolayısıyla dinlenme süresi artan çalışanın, iş veriminde yükselme olmuştur. Ayrıca, çalışma hayatının kendine ait stresinden uzak evde daha rahat bir şekilde çalışma hayatını deneyimleyen bireylerde yine iş verimliliği artmıştır.

4. Çalışan annelerin çocuklarını herhangi bir kuruma ya da yardımcı elemanlara bırakmadan kendilerinin ilgileniyor oluşları da büyük bir avantaj olarak karşımıza çıkmaktadır.

5. Çalışan anneler için sürecin zorlayıcı bir etkisi bulunmaktadır. Ev alanı, özel hayatın sürdürüldüğü mekândır. Fakat salgın sürecinde yaşam alanı ve özel hayatın sürdürüldügü mekân olan, aynı zamanda çalışma hayatının sürdürüldügü mekâna dönüşmüştür. Dolayısıyla özel alan, aynı zamanda kamusal alan haline gelmiştir. Bu anlamda özellikle evli ve çocuk sahibi bireyleri olumsuz yönde etkilemiştir. Tek bir mekân içerisinde rol çokluğunu (anne, baba, eş ve çalışan birey) yaşamak zorunda kalmışlardır.

6. Salgın sürecinde, boş vakitlerin değerlendirilebilecek alanlar kısıtlanmıştır. Bu noktada yaşam alanı olan ev, en çok vakit geçirilen bir mekân haline gelmiştir. Bu süreçte vakit geçirilen mekânların özellikle yaşam alanlarının önemi artmıştır. Bahçeli evler, balkonlu evler bu süreci daha iyi geçirmelerineneden olmuş, böyle evlerin önemi artmıştr. Ayrıca sosyal aktiviteler için, açık hava mekânları daha çok tercih edilir olmaktadır. Kapalı mekânlar virüsün yayılma tehlikesinden dolayı tercihler arasında yer almamaya başlamıştır. 
7. Salgin sürecinde kentte yaşamak büyük bir dezavantaj haline gelmiştir. Kentler, yapıları gereği insan yoğunluğu çok fazla olan mekânlardır. Dolayısıyla kentsel mekânlarda, insan akışı ve ortak kullanım alanları da yoğunlukta bulunmaktadır. Söz konusu yoğunluk, salgın döneminde büyük bir dezavantaj oluşturmaktadır. Ortak kullanım alanlarının ve insan yoğunluğunun fazla olması virüsün o kadar hızlı yayılmasına neden olmaktadır. Özellikle salgın döneminde daha izole bir yaşam, ortak kullanımların daha az nitelikte olduğu alanlar daha çok tercih edilmeye başlanmıştır. Bu anlamda salgin sürecinde kentte yaşayan insanların, kentteki yaşam pratiklerini sorgulamalarına, kendin avantaj ve dezavantajları üzerinde düşünmeye sevk etmiştir.

8. Kentsel mekânların cazibeliğini yitirdiğini söylemek zor olsa da, alternatif yaşam alanlarının oluşturulma eğiliminin fazla olduğu görülmektedir. İş, meslek, eğitim, sosyal aktivitelerin çok çeşitli ve imkân sahasın çok geniş olması, insanları kente bağlamaktadır. Bir yandan da Covid-19 salgınıla birlikte de kentsel mekânlarda yaşamanın zorluğu anlaşılmıştır. Bu anlamda insanlar, kentsel mekânlarda alternatif yaşam alanları oluşturmaya başlamıştır.

Sonuç olarak, toplumsal yaşam alanının önemli bir dinamiği haline gelen mekânlar, istek, ilgi ve ihtiyaçlar dâhilinde dönüşüme uğramaktadır. Covid19 salgını, yeni mekânlara ihtiyaç duyulduğunu göstermiştir. Alınan tedbirler kapsamında özel yaşamın merkezi olan ev, aynı zamanda eğitim mekânı, çalışma hayatının sürdürüldüğü mekân ve boş vakitlerin değerlendirildiği mekân olarak karşımıza çıkmaktadır. Bu durum, yaşam alanlarının, yeni eğilimler kapsamında üzerinde yeniden düşünülmesi ve tasarlanması gerektiğini göstermiştir. Ayrıca, kentte yaşamak başlı başına sorun teşkil ederken, salgın sürecinde risk ve tehlikenin odak merkezi olduğunu göstermiştir. Kentte yaşamak ne kadar zorsa, kente bağlayan dinamikler nedeniyle kentten uzak kalmak da bir o kadar zordur. Salgın ile birlikte kentten uzakta yaşamak fikri sabit olsa da pratikte pek mümkün olmadığı görülmektedir. Dolayısıyla kent yine cazibesini korumaktadır. Bu anlamda salgın süreci; sosyokültürel, psikolojik, ekonomik çerçeveler kapsamında kentte yaşamak sorgulanmakta, alternatif yaşam pratikleri tasarımı gündeme gelmektedir. 


\title{
Extended Abstract
}

\section{Covid-19 Pandemic from Sociological Aspect: City, Space and Social Life in Erzurum}

\author{
İlknur Beyaz Özbey \\ ORCID: 0000-0001-9809-9085
}

The main purpose of the study is to see what kind of altering effect the epidemic has on the space. With this aim, with the Covid-19 epidemic, it aims to understand how living spaces are designed as both educational spaces, working spaces and leisure spaces, and how these changes affect daily life, education and culture. In addition, the main problematic of the study is how urban spaces harbor risks and dangers with the epidemic, in this sense, urban spaces are questioned within the scope of their advantages and disadvantages, and ultimately how new living spaces are designed. In this problematic framework, in the study, the spatial transformation of the epidemic was tried to be understood by conducting in-depth interviews with the people living in Erzurum. The sample of the study consists of those in Erzurum city center. Within the scope of the sample, a total of 14 people, 7 of whom were women and 7 were men, were interviewed. While the interviews were conducted face to face with the interviewees; During the interview, with the permission of the interviewees, a tape recorder was used.

In general, we can design and change the space within our own needs. In this sense, the transformation experienced during the epidemic process has an effect on people's living spaces. Within the scope of the measures taken, the education was carried out at home, away from the school environment. This situation caused a corner of the house to be designed or transformed as an education space. At the same time, the fact that working life is flexible or away from work has caused people to spend most of their free time at home. Therefore, this situation caused one corner of the living space in the house to remain as a working space. This has several advantages and disadvantages. 
It saves time and economy for the employer and the employee. For the employer, it has been a great advantage to carry out the same work without the expenses of the working place and the expenses of the employees. In terms of employees, savings were achieved in the time and expense of commuting to the workplace. The rest period of the employee, who devotes the time he will spend on the road to himself, has increased. Therefore, there has been an increase in the work efficiency of the employee whose rest time has increased. In addition, work efficiency has increased in individuals who experience working life more comfortably at home away from the stress of working life itself.

It is a great advantage that working mothers take care of their children without leaving them to any institution or assistant staff. The process has a compelling effect for working mothers. Home area is the place where private life is maintained. However, during the epidemic, it has turned into a place where the living and private life is maintained, as well as a place where working life is maintained. Therefore, the private sphere has also become a public sphere. In this sense, it has especially affected individuals who are married and have children in a negative way. They had to experience the multiplicity of roles (mother, father, spouse and working individual) in a single space. During the epidemic period, the areas where leisure time can be spent are restricted. At this point, the home, which is a living space, has become a place where the most time is spent. In this process, the importance of the places where time is spent, especially the living spaces, has increased. Houses with gardens, houses with balconies caused them to go through this process better, and the importance of such houses increased. In addition, outdoor spaces are more preferred for social activities. Indoor spaces have started not to be among the choices due to the danger of the virus spreading. During the epidemic period, living in the city has become a major disadvantage. Cities are places with a high density of people due to their structures. Therefore, the flow of people and common use areas are also common in urban spaces. This density constitutes a major disadvantage during the epidemic period. The high common usage areas and the high density of people cause the virus to spread so quickly. Especially during the epidemic period, a more isolated life and areas with less common use have started to be preferred more. In this sense, it has prompted the people living in the city to question their life practices in the city during the epidemic process and to reflect on their own advantages and disadvantages.

Although it is difficult to say that urban spaces have lost their attractiveness, it is seen that there is a high tendency to create alternative living spaces. 
The diversity of jobs, professions, education, social activities and the wide range of possibilities connect people to the city. On the other hand, with the Covid-19 outbreak, the difficulty of living in urban spaces has been understood. In this sense, people have begun to create alternative living spaces in urban spaces. The Covid-19 outbreak has shown the need for new spaces. Within the scope of the measures taken, the home, which is the center of private life, also appears as a place of education, a place where working life is carried out and a place where leisure time is spent. This situation has shown that living spaces need to be rethinked and designed within the scope of new trends. In addition, it has shown that while living in the city is a problem in itself, it is the focus of risk and danger during the epidemic process. The harder it is to live in the city, the more difficult it is to stay away from the city due to the dynamics that connect it to the city. Although the idea of living away from the city with the epidemic is fixed, it seems that it is not possible in practice. Therefore, the city still maintains its charm.

\section{Kaynakça/References}

Afacan, E. ve Avcı, N. (2020). Koronavirüs (Covid-19) örneği üzerinden salgın hastalıklara sosyolojik bir bakış. Avrasya Sosyal ve Ekonomi Araştırmaları Dergisi,7(5), 1-14.

Akbaş, E. (2020). Covid-19'un toplumsal etkileri. İ. Demir (Ed.). Kovid-19 ve sonrası disiplinlerarası bir yaklaşım içinde (36-41). ULISA.

Altunışık, R., Çoşkun, R., Bayraktaroğlu, S. ve Yıldırım, E. (2007). Sosyal bilimlerde araştırma yöntemleri: SPSS uygulamal. Sakarya: Sakarya Yayincllk.

Alver, K. (2007). Siteril hayatlar: kentte mekânsal ayrışma ve güvenlikli siteler. Ankara: Hece Yayınları.

Atabeyoğlu, Ö. ve Turgut, H. (2009). Tarihi bir kentin değişimi: Erzurum kenti. itüdergisila mimarlik, planlama, tasarm, 8(1), 41-53.

Castells, M. (1991), Kent, sinıf, iktidar, Asuman Erendil (Çev.). Ankara: Bilim ve Sanat Yayınları.

Çavuşoğlu, E. (2016). Türkiye kentleşmesinin arkeolojisi. İstanbul: Ayrıntı Yayınları.

Göka, S.. (2001). İnsan ve mekân. İstanbul: Pınar Yayınları.

Gönül, K. (2020). Salgın ve yeni çalışma biçimleri. Kamuda Sosyal Politika, 13(40), 49-57.

Güleç-Solak, S. (2017). Mekân-kimlik etkileşimi: kavramsal ve kuramsal bir bakış. MANAS Sosyal Araştırmalar Dergisi, 6(1). 13-37.

Gür, Ş, Ö., (1996). Mekan örgütlenmesi. Trabzon: Gür Yayınları.

Harvey, D. (2003). Sosyal adalet ve şehir. Mehmet Moralı (Çev.), İstanbul: Metis Yayınları. İnceoğlu, M. ve Aytuğ, A. (2009). Kentsel mekânda kalite kavramı. MEGARON, 4(3):131-146.

Kahraman, M. D. (2014). İnsan ihtiyaçları ve mekansal elverişlilik kavramları perspektifinde yaşanılırlık olgusu ve mekansal kalite. Planlama, 24(2):74-84 
Kolukırık, S. (2010). Mekân, kültür ve kimlik: Isparta Tahtacılarında mekânın sosyal anlami. Journal of World of Turks, 2(2):87-100.

Kurt, A. A. (2013). Bilimsel araştırma yöntemleri. Eskişehir: Anadolu Üniversitesi Yayınları. Lefebvre, H. (2015), Mekanın üretimi. Işık Ergüden (Çev.). İstanbul: Sel Yayınları.

Odabaş, U. K. (2018). Tarihsel süreçte kamusal alanın yapısal dönüşümü ve Habermas. Atatürk Üniversitesi Sosyal Bilimler Enstitüsü Dergisi, 22(Özel Say1): 2051-2066.

Paköz, M. Z. (2020). Azman kentlerin sonu mu? Salgın sonrasında kentsel planlama. İ. Demir (Ed.). COVID-19 salgınının sosyolojik analizi içinde (23-28). Erişim Adresi: https://tyap.net/mediaf/TYAP_korona_analizleri.pdf

Taştan, C. (2020). Kovid-19 salgını ve sonrası psikolojik ve sosyolojik değerlendirmeler. O. İmga ve U. Ayhan (Der.), KOVID-19 salgını ve sonrası toplum, devlet ve küresel sistem içinde (13-47). Ankara: Polis Akademisi Yayınları.

Tezcan, M. (1996). Eğitim sosyolojisi, Ankara: Feryal Matbaası.

Zaman, M., Sevindi, C. ve Birinci, S. (2018). Tarihi yolların buluştuğu Erzurum şehrindeki beşeri turistik eserler. Atatürk Üniversitesi Sosyal Bilimler Enstitüsü Dergisi, 22 (Özel Say1), 581-601.

Zeybekoğlu-Akbaş, Ö. ve Dursun, C. (2020). Koronavirüs (Covid-19) pandemisi sürecinde özel alanına kamusal alanı sı̆̆dıran çalışan anneler. Avrasya Sosyal ve Ekonomi Araştırmaları Dergisi, 7(5): 78-94. 